
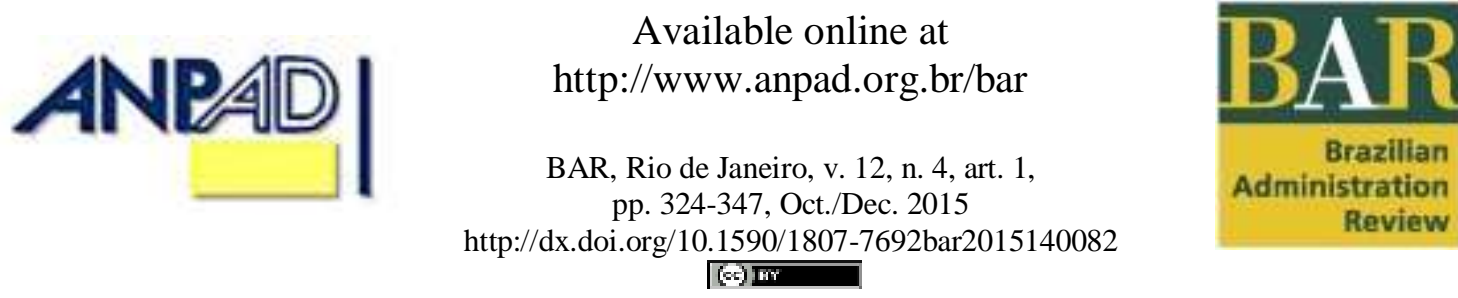

\title{
The Organizational Change Process: Its Influence on Competences Learned on the Job
}

Elaine Rabelo Neiva Universidade de Brasília - UnB/CCA

Catarina Cecília Odelius Universidade de Brasília - UnB/CCA

Larissa Dutra Ramos Universidade de Brasília - UnB/CCA

Received 10 December 2014; received in revised form 18 September 2015; accepted 30 September 2015; published online 15 December 2015.

Editor's note. Fabio Vizeu served as Action Editor for this article. 


\begin{abstract}
This study was developed in a Brazilian court that was subjected to the introduction of e-process, and bears the following objectives: (a) describe the context of changes in terms of planning and perceived risk degree; (b) describe the results perceived after the introduction of the e-process; (c) describe the support to learning and the competences learned during the e-process implementation; (d) identify the links between variables of changing context, support to learning and the competences learned during the introduction of the e-process at the Higher Justice Court. 219 civil servants participated in the study, which used scales of changing context, results of the change of competences and support to learning. Scales were subjected to exploratory factor analysis with robust statistical indexes and three multiple regressions to test the associations between variables. Results pointed out that characteristics of the change process and support to learning affect learned competences.
\end{abstract}

Key words: organizational change; learning; competences learned; e-process. 


\section{Introduction}

Despite the large number of articles about organizational change, few systematically identify the aspects of change that influence individual behavior (Neiva \& Paz, 2012; Nery \& Neiva, 2015; Rafferty \& Griffin, 2006). As context and process factors of organizational change, some studies identify the following aspects of change that are relevant and affect individuals: the frequency, scope, planning the change, communication and degree of psychological uncertainty (Kalimo, Taris, \& Schaufeli, 2003; Rafferty \& Griffin, 2006; Self, Armenakis, \& Schrader, 2007).

Authors like Kalimo, Taris and Schaufeli (2003), Rafferty and Griffin (2006) and Maes and Van Hootegem (2011) state that interventions to organizational change are part of a context that brings some dimensions and attributes which can be considered in phenomenon description. Maes and Van Hootegem (2011) listed eight attributes that dynamically describe organizational change: Control refers to the emerging or planned change; Scope - the continuum from adaptation to transformation; Frequency - the amount of organizational change that is happening; Progress - the number of stages to implement change; Time - the time to implement change; Speed - the rhythm of actions; Goals - the stated end intended by the changes; Leadership style - the leadership style and decision-making is particularly defined by the degree of employee participation and may vary according to cooperation and participation levels.

The great landmarks of the international literature conceive of learning as a process that generates new individual behaviors and changes at the organizational level (Santa \& Nurcan, 2015). However the relationship between learning and organizational change still requires some investigation, especially regarding the relationship between the levels of these phenomena.

This study starts from the premise that the context of organizational change can generate learning that is expressed by work competences. Work competences express the behavioral changes necessary for organizational changes to occur. Individual engagement in a learning action takes place when the need arises for acquiring knowledge and skills to fill existing gaps or deficits in competences and, also, to enrich existing repertoire (Ausubel, 2003). The organizational change process provides the background required to develop such competences in the working environment (Abbad \& BorgesAndrade, 2014; Santa \& Nurcan, 2015).

Brandão, Borges-Andrade and Guimarães (2012) and Moraes and Borges-Andrade (2010) emphasize that the manifestations of competence through proper behaviors in work are conditioned by the learning context where these were developed, while Pandey and Guha (2014) show that the learning process in changing contexts is anchored in informal on-the-job learning, and change management takes place through strategies to foster the required competences. Rafferty and Griffin (2006), in turn, highlight the need for studies to systematically identify changing aspects important to individuals that also influence their behaviors.

In face of these arguments, this study, based on the analysis of a change process, tried to answer the following questions: what were the relevant organizational change dimensions as perceived by individuals in their working environment? Which results of the implemented changes were perceived? Was learning supported during the organizational change? Which competences were learned during the organizational change? How do perceptions about characteristics of the changing context influence learning and competences learned? How has the support to learning influenced the competences learned? In brief, what are the links among the variables of changing context, change results, support to learning and competences learned during the introduction of the e-process in the Highest Justice Court?

The major contribution of the study is to establish relationships between organizational change, learning and competences learned at work, conceiving of learning as a phenomenon at the individual level that can reverberate to other levels, such as groups and organizations. Thus organizational changes are implemented through this learning reverberation. Therefore, the study contributed to understand the context, process and impacts of changes in an understudied environment: the Brazilian judiciary system 
(Guimarães, Odelius, Medeiros, \& Santana, 2011). The theoretical basis used comprises topics related to organizational change and its link with learning, support to learning, and performance of the competences learned. The method, results, discussion and conclusion are discussed after the theoretical basis.

\section{Organizational Change}

Despite the abundance of literature with advice on change management for practitioners, a lack of research on how these practices work and on their effectiveness subsists (Raineri, 2011). This remains predominantly true for most popular approaches to change, including Kotter's process. A thorough study of the literature conducted by Appelbaum, Habashy, Malo and Shafiq (2012) revealed that most evidence points to data that has been compiled by Kotter himself. Writers on change management seem to have discussed Kotter's process as if it had been tested and verified, with the popularity of the model based more on its accessibility than on any scientific verification of its efficacy.

To perform systematic analysis of organizational change, some authors emphasize the need for specifying the characteristics of organizational change context, and evaluating the results (Bartunek \& Woodman, 2015; Maes \& Van Hootegem, 2011; Neiva \& Paz, 2012; Nery \& Neiva, 2015). Organizational change can be considered in a specific context where transformation takes place in the organization within a broader institutional context (Hatch \& Ehrlich, 1993). Maes and Van Hootegem (2011) listed eight attributes that dynamically describe organizational change: Control - refers to the emerging or planned change; Scope - the continuum from adaptation to transformation; Frequency - the amount of organizational change that is happening; Progress - the number of stages to implement change; Time - the time to implement change; Speed - the rhythm of actions; Goals - the stated end intended by the changes, Leadership style - the leadership style and decision-making is particularly defined by the degree of employee participation and may vary according to cooperation and participation levels.

Moreover, literature in this field has attempted to track this context based on the core features that could characterize it. Some studies (Bartunek \& Woodman, 2015; Maes \& Van Hootegem, 2011; Neiva \& Paz, 2012; Nery \& Neiva, 2015), like that by Rafferty and Griffin (2006), have identified four different traits of change: frequency, scope, planning of change, and degree of psychological uncertainty.

Another factor typical to change processes explored by researchers concerns previous experiences with change processes and future perspectives with new change processes (Cunningham, 2006; Devos, Buelens, \& Bouckencooghe, 2007; Kalimo et al., 2003; Nery \& Neiva, 2015). Cunningham (2006) relates the intensity of changes and previous experiences with employee commitment during interventions for change. Devos, Buelens and Bouckencooghe (2007), in turn, have associated the degree of risk of change context with individuals' openness to accept change processes and show the intended behaviors, while Kalimo et al. (2003) have associated the frequency of occurrence of interventions for change and the perspectives of future interventions with the perception of fairness in organizations and individuals' well-being.

Moreover, Self, Armenakis and Schraeder (2007) believe that factors such as the degree of risk of changes, degree of impact generated by changes on employees and the intensity of communication affect employees' affective reactions to the interventions for changes, while Gravenhorst, Werkman and Boonstra (2003) emphasize the importance of the support perceived during the change process.

Still focusing on aspects that influence the context of organizational change, Nery and Neiva (2015) identified two sets of core characteristics that have repercussions on employees' behaviors: planning and readiness to changes to be made and degree of risk and intensity of changes experienced by individuals. However, context and process change characteristics have not been linked to the learning 
process and how that context generates new behaviors desired by organizational change still remains unexplained (Nery \& Neiva, 2015).

Beviláqua-Chaves (2007) identified that organizational contexts of change with different characteristics are associated with different learning strategies in the work environment. According to the author, episodic changes generate more reflexive learning strategies, while continued changes enable behavioral strategies that seek interpersonal help.

In short, this academic research has the potential to provide significant benefits to practitioners and to change theories, as it evaluates the links between organizational and individual levels as well as creating and testing new concepts in the organization change literature.

\section{Learning and Organizational Change Context}

Learning is the process of improving actions through better knowledge and understanding (Fiol $\&$ Lyles, 1985), and despite an amount of research on the main learning topics such as learning support, informal learning at work and individual attributes that promote learning, several important gaps remain in the understanding of why some people go through the learning process faster than others and in understanding how learning experiences promote organization change. In trying to understand how learning fosters organizational change, several authors have created concepts such as organizational learning and learning organizations whose definitions include the metaphorical use of this concept.

Armenakis and Bedeian (1999) affirm that change implementation necessarily demands encouraging individuals to adopt new behaviors to allow the accomplishment of the intended changes. In this focus, the phenomenon is related to learning in the working environment because, according to Abbad and Borges-Andrade (2014) and the cognitive and behavioral approaches, learning has to do with changes occurring in individuals' behaviors (repertoire of knowledge, skills and attitudes) due to their interactions with other persons and the external environment. In the light of cognitive approaches, these changes involve individual processes of purchase (attention, perception, and codification), retention or memorization, generalization and learning transfer (Abbad \& Borges-Andrade, 2014).

This cognitive research tradition has been developing apart from many other tendencies, such as organization learning, learning organizations, change management, etc. These concepts have been largely criticized for lack of conceptual clarity and operational imprecision (Santa \& Nurcan, 2015). In a learning organization, learning takes place at the individual, team and organizational levels (Karp, 2006). These three levels work together and influence one another (Kofman \& Senge, 1993). Organizational learning in turn refers to the idea that the organization entity learns as a whole (Karp, 2006). However, according to these tendencies, there is an individual actor bias in the literature, and theories still emphasize the role of individuals as active agents (Huysman, 1999). This might be the result of seeing the individual as the primary learning entity in the organization (Dodgson, 1993). On the other hand, although individual learning is necessary, it is not a sufficient condition for organizational learning (Gould, 2000). The latter is a collective process (James, 2003; Watkins \& Marsick, 1993) and groups or teams are the main bridge through which this process is carried out. Teams are the place where the rubber meets the road; if teams cannot learn, the organization cannot learn (Senge, 1990). The literature also does not both foster the relationship between the levels and support it with empirical data (Santa \& Nurcan, 2015).

That prior theoretical trend that supports learning as an individual phenomenon has shown significant empirical support for its inferences and concepts. According to Abbad and Borges-Andrade (2014) several factors affect the organizational learning process. Some factors are related to organizational functioning, the working environment and tasks performed by individuals. These can determine if a learning action is successful or not. Here, factors inserted in the work context should support learning actions (Coelho \& Borges-Andrade, 2008). 
Learning support actions happen at the group or team level and are promoted by leaders according to Coelho and Borges-Andrade (2008). The lessons learned, influenced by an organizational context and by the characteristics of relationships among employee groups, generate results for individuals, groups and organizations. Battilana, Gilmartin, Sengul, Pache and Alexander (2010) have proposed that leadership fosters the competences learned during organization change processes through learning support provided to employees.

The organizational context can support effective changes (Gravenhorst, Werkman, \& Boonstra, 2003) and also generate support for the learning of behaviors demanded by interventions (Coelho \& BorgesAndrade, 2011). The support to informal learning on the job has been understood as the individual's analysis of the psychosocial support they perceive when performing informal learning actions on the job (Coelho \& Borges-Andrade, 2011). According to Gubbins and MacCurtain (2008), in turn, support to learning bears the purpose of showing individuals standards of social participation in the organizational context, determining the kinds of behavior required during social interactions related to the performance of their everyday work and expected performance. Freitas and Brandão (2006) suggest that learning is the process whereby individuals acquire competencies (knowledge, skills and attitudes).

The context of organizational change and the context that enables learning provide the required conditions for the informal learning process to occur, while work relations enable interactions characterized as a means to develop new competencies that will be further expressed by satisfactory or excellent performance. Thus we can present the broad initial hypothesis of this study:

H1: The attributes of context and organizational change process and the change perceived results positively affect competences acquired by employees.

H2: Learning support actions in the organization positively affect the competences acquired by employees during change processes.

\section{Organizational Change, Results and Performance of Competences Learned}

Armenakis and Bedeian (1999) divide the research on organizational change into four broader topics: content, context, processes and results. Research involving content approach the targets of the change process or that will be object of the intervention. Research about changes on internal and external organizational environments that effect to what extent the organization meets such demands are classified as context research, while the study of change processes, their stages and characteristics are approached by the topic of process. Finally, the topic of results comprises the research that approach the results of organizational changes, which could be adopted as criteria to evaluate the success or failure of changes. These criteria could be indicators such as productivity and financial returns, or behavioral and affective criteria.

Neiva and Paz (2012) advocate for the idea that the way individuals perceive results is one of the mechanisms for evaluating change. Another result of organizational change would be the manifestation of competences required by individuals (Coetzee, Visagie, \& Ukpere, 2013; Pandey \& Guha, 2014).

The topics of competence and learning in organizations, despite being deeply studied in the last few decades, remain characterized by their divergences regarding conceptualization and approach to phenomena. The concept of competence is considered to be broad, complex and multifaceted (Brandão, Borges-Andrade, \& Guimarães, 2012) and some authors associate the notion of competence not only with persons, but also with work teams and organizations (Coetzee et al., 2013; Freitas \& Brandão, 2006; Pandey \& Guha, 2014).

Zarifian (1999), in turn, refers to meta-cognition and work-related attitudes as components of competencies. For the author, competence is the capacity of an individual to take on responsibilities in 
the face of complex work situations, and the systematic reflection in work that allow professionals to handle unique events.

Brandão, Borges-Andrade and Guimarães (2012) emphasize that individuals' performance expresses their competences and, therefore, recommend describing human competences as referential of performance; therefore, an individual should show competence through the adoption of some behaviors observed on the job.

Competences are disclosed when individuals react in the face of professional situations posed to them (Zarifian, 1999) and serve as a link between individual conduct and organization strategy. According to Abushawish, Bin Ali and Bin Jamil (2013), Pandey and Guha (2014), Coetzee, Visagie and Ukpere (2013) and Cardoso (2009), managerial competences are most explored in contexts of organizational change, although learning new experiences is the core interest in those contexts. Armenakis and Bedeian (1999) affirm that change implementation necessarily demands encouraging individuals to adopt new behaviors to allow the accomplishment of the intended changes, although few studies explore that relation.

Finally, the literature about the context of organizational change has progressed in terms of characterization, allowing their tracking and measurement, as well as the analysis of association links between the context characteristics and their impact on individuals and groups in organizations. In line with this tendency, this research aims to identify the characteristics of the change context and link these to the results of perceived change, support to learning and the competences learned during the change process. This paper defines context as the dimensions that characterize organizational change in terms of planning, degree of risk and the intensity with which it affects participants (Cunningham, 2006; Devos et al., 2007; Kalimo et al., 2003). The results of organizational changes perceived by individuals are adopted as criteria to evaluate the success or failure of changes (Armenakis \& Bedeian, 1999). The support to informal learning on the job is defined as the individual's analysis about the psychosocial support they perceive when performing informal learning actions on the job (Coelho \& Borges-Andrade, 2011). Human or professional competences, in turn, are considered to be synergistic combinations of knowledge, skills and attitudes, expressed by the professional performance in a given organizational context, and which add value to individuals and organizations (Carbone, Brandão, \& Leite, 2005). Therefore we present the third broad hypothesis of this study:

H3: The perceived change results will affect the competences learned by employees during change processes.

\section{Method}

In principle, this topic characterizes the Court where the change object of study took place, followed by the procedures of data collection and analysis.

\section{Introduction of the e-Process in the Court}

The Brazilian Judiciary Power reform is related to the constitutional reforms that culminated with the enactment of a new Constitution in 1988. According to Sadek and Cavalcanti (2003), when Brazil returned to a civil regimen in 1985, after more than 20 years of military regimen, there was an avalanche of legal suits that reflected the restrained demand during the past period. The 1988 Constitution increased the Brazilian justice system capacity for supervising public and private institutions, and for protecting individual and social rights. The Judiciary was empowered and granted the prerogative of determining the constitutionality of acts emanating form the legislative and executive powers of the government (Sadek \& Cavalcanti, 2003). 
The STJ was established by the 1988 Federal Constitution, and is the highest court of appeal in Brazil for infra-constitutional cases (Constituição da República Federativa do Brasil, 1988/2001). The STJ is tasked with the duty of hearing the appeals submitted to the state courts of Brazil and the five federal regional courts, and prosecute cases involving ordinary crimes perpetrated by state governors, state judges, employees of auditing agencies, and federal judges in regional electoral sessions, as well as Labor Justice Judges.

The consensus on the need for quicker and more efficacious Judiciary Power led to the creation of the National Justice Council (CNJ) and the National Institute of the Justice System Internal Affairs which reports to the Council. The CNJ is responsible for human resources development and other administrative aspects of the Judiciary Power of Brazil, notably aspects related to administrative control and transparency. In that context, the programs to enhance the judiciary system agility became a priority (Campos \& Rizzo, 2009).

The STJ has promoted several changes throughout its history in an attempt to modernize the judicial system, including the adoption of strategic management and projects and actions to optimize work processes and manage quality are worth of mentioning. The latest organizational change of the Court was mainly focused on the adoption of electronic procedures to deal with the proceedings in the institution. The introduction of electronic procedures to deal with legal proceedings in the Court involves scanning physically submitted processes; elaborating and adjusting the e-system that will manage legal proceedings; and reviewing work processes and nature of tasks to draft and incorporate rules and juridical procedures required to deal with legal proceedings (Guimarães et al., 2011).

\section{Data collection procedure}

This research analyzed the characteristics of the context of change, the phenomena of support to learning, competences learned (knowledge, skill and attitude) in the context of organizational change, and the result of change as perceived by the Court's civil servants, as well as the links among these phenomena, which characterizes this study as a field, descriptive and correlational research.

Data were collected from June to July 2012 through electronic questionnaires made available to 1,400 civil servants of the organization directly dealing with the e-process. The respondents worked at Offices, Coordination Units and Sections $\left(1^{\text {st }}, 2^{\text {nd }}\right.$ and $\left.3^{\text {rd }}\right)$ and the six Panels, in addition to the Special Court.

\section{Sampling}

309 civil servants accessed the questionnaire, but only 219 completed it. Among respondents, $50.2 \%$ are male, $24.7 \%$ hold managerial offices, $64.8 \%$ held an applied post-graduate degree and $23.7 \%$ held an academic higher education degree, $41.6 \%$ were 40 to 49 years old, and $50.7 \%$ had worked at the Court from1 to 8 years.

\section{Instruments}

The data collection instruments were based on the literature, or were duly adjusted former research instruments. Instruments were designed with scales of 11 points (0 to 10): Scale of context of change and scale of the change results were adjusted to this study (Nery \& Neiva, 2015); Scale of competences learned were based on previous studies (Brandão, Borges-Andrade, \& Guimarães, 2012; Moraes \& Borges-Andrade, 2010) and interviews with the Court civil servants; and, Scale of support to learning (Coelho \& Borges-Andrade, 2008, 2011; Pantoja \& Borges-Andrade, 2004). Scales were adjusted to the reality of the organization surveyed through data obtained from the establishment of 13 focal groups with 4 to 8 civil servants, totaling 72 civil servants. The anchors used in scales approach how often respondents perceive the related aspects. The scales and items, including their validity, can be found in Appendix section. 


\section{Data analysis procedure}

All scales were submitted to exploratory factorial analysis to evaluate the stability of the factorial structure found in the sampling of this research. Indexes point out KMOs higher than 0.90 for all instruments, factorial loads superior to 0.4 , and Cronbach's alphas higher than 0.70 , evidencing robust statistic indexes. The continued learning support instrument presented the same validation structure (Coelho \& Borges-Andrade, 2008). The context of changes instrument also presented the factorial structure found by Nery and Neiva (2015). All instruments presented the aforementioned variance above $54 \%$. Table 1 discloses a summary of the factors of instrument and of validity data for this sampling.

Table 1

Indications of Validity and Composition of Instruments

\begin{tabular}{|c|c|c|c|c|}
\hline Scale & Factors & $\begin{array}{l}\text { Number of } \\
\text { items }\end{array}$ & $\begin{array}{l}\text { Factorial } \\
\text { Loads }\end{array}$ & $\begin{array}{c}\text { Cronbach's } \\
\text { Alpha }\end{array}$ \\
\hline \multirow{2}{*}{$\begin{array}{c}\text { Scale of Context of } \\
\text { Organizational Change - } \\
\text { two factors }\end{array}$} & Planning and Readiness & 9 & $\begin{array}{c}\text { From } 0.65 \text { to } \\
0.78\end{array}$ & 0.79 \\
\hline & Degree of risk and Intensity & 7 & $\begin{array}{l}\text { From } 0.55 \text { to } \\
0.76\end{array}$ & 0.86 \\
\hline \multirow{2}{*}{$\begin{array}{c}\text { Scale of Results of the } \\
\text { Organizational Change - } \\
\text { two factors }\end{array}$} & $\begin{array}{l}\text { Efficiency and Agility of } \\
\text { the Organization }\end{array}$ & 9 & $\begin{array}{l}\text { From } 0.55 \text { to } \\
0.81\end{array}$ & 0.76 \\
\hline & $\begin{array}{l}\text { Changes to Relationships } \\
\text { and People Management }\end{array}$ & 7 & $\begin{array}{l}\text { From } 0.55 \text { to } \\
0.79\end{array}$ & 0.82 \\
\hline \multirow[t]{2}{*}{ Scale of Support to learning - } & Unit Support & 9 & $\begin{array}{l}\text { From } 0.65 \text { to } \\
0.78\end{array}$ & 0.85 \\
\hline & Leadership Support & 11 & $\begin{array}{l}\text { From } 0.65 \text { to } \\
0.76\end{array}$ & 0.80 \\
\hline \multirow[t]{3}{*}{ Scale of Competences Learned - } & $\begin{array}{c}\text { Problem-solving and work } \\
\text { management }\end{array}$ & 11 & $\begin{array}{c}\text { From } 0.55 \text { to } \\
0.77\end{array}$ & 0.80 \\
\hline & E-process operation & 09 & $\begin{array}{l}\text { From } 0.65 \text { to } \\
0.78\end{array}$ & 0.82 \\
\hline & $\begin{array}{l}\text { Adoption and adjustment of } \\
\text { rules and procedures }\end{array}$ & 12 & $\begin{array}{c}\text { From } 0.55 \text { to } \\
0.81\end{array}$ & 0.79 \\
\hline
\end{tabular}

Data were processed using SPSS software version 18, and descriptive, factorial and multiple regression analyses were performed with the factors identified by the instruments. 


\section{Context of Changes in the Court, Result of Changes, Support to Learning and Competences Learned}

The context of changes in the Court was characterized by two factors: Planning and Readiness of Changes and Degree of risk and Intensity of changes. Aspects related to planning and the civil servants readiness to the introduction of e-process were not as sharply perceived by the respondents. However, considering the high standard deviation and the variation coefficient above 0.25 , there are good indications to consider that this aspect is perceived in different ways by the different groups of the organization. The degree of risk and the intensity of changes were homogeneously perceived as high, as the standard deviation and variation coefficient are low $(\mathrm{VC}=0.20$.)

Table 2

Descriptive Data of the Factors of Change Context

\begin{tabular}{lcc}
\hline & Planning and Readiness & Degree of Risk and Intensity \\
\hline Missing Data & 0 & 0 \\
Mean & 5.97 & 7.80 \\
Median & 6.26 & 8.15 \\
Standard Deviation & 2.29 & 1.55 \\
Variation coefficient & 0.38 & 0.20 \\
\hline
\end{tabular}

The results perceived after the e-process introduction were pooled in two factors: Efficiency and Agility of the Organization, Changes in Relationships and People Management. The results of the change process are homogeneously perceived by respondents. Both the efficiency and agility resulting from the e-process introduction and the changes in relationships and people management have low standard deviations and variation coefficient. The perception of efficiency and agility resulting from the introduction of the e-process is very strong among respondents, but this is not true for changes in relationships and proper assignment and distribution of work among people.

Table 3

Descriptive Data about the Perceived Results of Changes

\begin{tabular}{lcc}
\hline & Efficiency and Agility & $\begin{array}{c}\text { Changes to Relationships and } \\
\text { People Management }\end{array}$ \\
\hline Missing Data & 20 & 20 \\
Mean & 8.74 & 5.98 \\
Median & 9.25 & 6.00 \\
Standard Deviation & 1.56 & 1.45 \\
Variation coefficient & 0.18 & 0.24 \\
\hline
\end{tabular}

Support to learning during changes was pooled in two factors: Unit Support and Leadership Support. These factors are quite close to those obtained in the initial validation by Coelho and BorgesAndrade (2011). The respondents' perception on both factors was very close and somewhat homogeneous (variation coefficient of 0.25 to 0.30.). The leadership support was slightly more emphasized than the unit support (work group) as the median to leadership support is higher than the median to unit support. A paired test has also been performed regarding the difference between means, confirming stronger leadership support $(\mathrm{t}=2.53 ; \mathrm{p}=0.012$.). 
Table 4

Descriptive Data of Support to Learning

\begin{tabular}{lcc}
\hline & Unit Support & Leadership Support \\
\hline Missing Data & 32 & 33 \\
Mean & 7.18 & 7.36 \\
Median & 7.79 & 8.07 \\
Standard Deviation & 2.30 & 2.26 \\
Variation coefficient & 0.30 & 0.28 \\
\hline
\end{tabular}

The competences learned by civil servants during the change process were pooled in three factors: competences to solve problems and manage work, competences to operate the e-process and competences of use, and adjustment of rules and procedures. The competences to operate the e-process were those developed more during changes, besides being homogeneously perceived as having been developed among respondents. The competences of adopting and adjusting the rules and procedures were perceived as less developed and with more difference among participants. The competences of solving problems and managing work were of median intensity, with short homogeneity. The lack of homogeneity resulted from the fact that some developed the competence more, while others perceived less development.

Table 5

Descriptive Data of Competences Learned During the Change Process

\begin{tabular}{lccc}
\hline & $\begin{array}{c}\text { Problem-solving and } \\
\text { work management }\end{array}$ & E-process operation & $\begin{array}{c}\text { Adoption and } \\
\text { adjustment of rules and } \\
\text { procedures }\end{array}$ \\
\hline Missing Data & 44 & 43 & 44 \\
Mean & 6.55 & 7.60 & 5.90 \\
Median & 6.65 & 7.92 & 6.00 \\
Standard Deviation & 2.33 & 1.92 & 2.32 \\
Variation coefficient & 0.35 & 0.24 & 0.39 \\
\hline
\end{tabular}

\section{Relationships among Variables}

Three multiple regressions were performed using the competences learned as dependent variables and the other variables and potential predictors of competences. Greater explanation regarded learning of competences to operate the e-process, whose model reported $\mathrm{R}^{2}$ of 0.54 , disclosing an explanatory power of 54\%. These results are depicted in Table 6 . The predictors for the competences of e-process operation are the perception of efficiency and agility and the changes in relationships and people management. The respondents that more frequently perceived that the adoption of e-process brought efficiency, agility, changes to relationships and people management are those who more intensively developed the operational competences referring to handling the justice system and the electronic processing of procedures. 
Table 6

\section{Regression Coefficients}

\begin{tabular}{|c|c|c|c|c|c|c|}
\hline \multirow[b]{2}{*}{ Model } & \multicolumn{2}{|c|}{$\begin{array}{l}\text { Predictors of the } \\
\text { competence: problems } \\
\text { resolution and work } \\
\text { management }\end{array}$} & \multicolumn{2}{|c|}{$\begin{array}{l}\text { Predictors of the } \\
\text { competence: adoption } \\
\text { and adjustment of rules } \\
\text { and procedures }\end{array}$} & \multicolumn{2}{|c|}{$\begin{array}{c}\text { Predictors of the } \\
\text { competence: e-process } \\
\text { operation }\end{array}$} \\
\hline & Beta & Sig. & Beta & Sig. & Beta & Sig. \\
\hline Constant & -0.86 & 0.58 & 1.94 & 0.171 & -2.26 & 0.03 \\
\hline Planning and Readiness & 0.13 & 0.18 & 0.27 & 0.007 & 0.04 & 0.59 \\
\hline Degree of risk and Intensity & 0.05 & 0.67 & -0.15 & 0.182 & 0.09 & 0.29 \\
\hline Efficiency and Agility & 0.13 & 0.13 & 0.06 & 0.500 & 0.46 & 0.00 \\
\hline $\begin{array}{c}\text { Changes to relationships and } \\
\text { People Management }\end{array}$ & 0.17 & 0.02 & 0.21 & 0.005 & 0.14 & 0.012 \\
\hline Unit Support & -0.04 & 0.80 & 0.08 & 0.581 & 0.06 & 0.56 \\
\hline Leadership Support & 0.31 & 0.02 & 0.11 & 0.429 & 0.14 & 0.18 \\
\hline $\mathrm{R} 2$ & 0.31 & & 0.20 & & 0.54 & \\
\hline $\mathrm{R} 2$ adjusted & 0.30 & & 0.18 & & 0.53 & \\
\hline $\mathrm{F}$ for $\mathrm{R} 2$ & $2.39 *$ & & $2.14^{*}$ & & $2.79 *$ & \\
\hline
\end{tabular}

Note. F for R2, Beta coefficients and their standard error for the regression analyses using the independent variables as predictors of competences learned. Standard errors for beta coefficients in parenthesis (*pb0,05;**pb0,01; n/s: not significant).

The second model for regression reached an explanatory power of $20 \%\left(\mathrm{R}^{2}=0.20\right)$ for the competence of adoption and adjustment of rules and procedures. This competence is predicted by the degree of planning and readiness perceived by civil servants, and by the perception of changes in relationships and people management. These results are depicted in Table 6. Generally speaking, it is worth highlighting that people who more intensively developed this set of competences are those who perceived planning and readiness to carry out changes and those who perceived that changes have generated positive impacts on relationships and on human resources management in the court.

The third model for regression reached an explanatory power of $31 \%\left(\mathrm{R}^{2}=0.31\right)$ for the competence problem resolution and work management. The competences of problem resolution and work management are complex, of a higher order (Abbad \& Borges-Andrade, 2014) and essential to the success of change programs based on the classifications of skills at work. The competences of problems resolution and work management are associated with changes in relationships and people management and to learning support provided by leadership. These results are depicted in Table 6. Generally speaking, it is worth highlighting that people who more intensively developed this set of competences are those who perceived that changes have generated positive impacts on relationships and people management, additionally to having perceived the leadership support for informal and continued learning on the job.

The results achieved provide support for all hypotheses, which reinforces the idea that organizational and work related group aspects accentuate the possibility of learning at work and indicate empirical relationships between learning process, individual behavior and organizational change. Such kind of relationships have been continuously speculated by the organizational learning literature and learning organizations (Abbad \& Borges-Andrade, 2014; Brandão, Borges-Andrade, \& Guimarães, 2012; Nery \& Neiva, 2015). 


\section{Discussion and Findings}

First of all, it is important to emphasize that all study objectives were fulfilled. As regards the description of the change context, the poor planning perceived by individuals is one of the most concerning aspects related to public administration. In line with the results achieved by Nery and Neiva (2015) and Neiva, Goulart, Fussi and Nery (2012), the low level of planning perceived, and the high index of degree of risk and intensity of changes perceived make this process more averse for individuals who lose their reference in the work environment.

The results perceived for change, in terms of agility and efficiency of the organization, were largely mentioned in the individuals' response, while changes to relationships and people management were not perceived by respondents. These results corroborate the assertion by Armenakis and Bedeian (1999) that results involving productivity are more frequently employed as criterion for the success of changes. This result bears important implications for people management in organizations, because it challenges to what extent people management is ready to take an important role in the processes of organizational change as advocated by several authors in this field (Legge, 2006; Mascarenhas, 2009; Mascarenhas \& Kirchbaum, 2008). This result corroborates managers' perceptions that people management practices occur dissociated from change processes (Guest \& Conway, 2011; Rees \& Johari, 2010).

The research participants perceived that leadership support and the support of the unit work group were present throughout the change process, thus corroborating the previous results achieved by Coelho and Borges-Andrade (2011) according to which this phenomenon entails conditions more favorable to learning competences.

Competences learned, in turn, were those related to the system operation and, to a lesser extent, those of adoption of rules and adjustment of procedures, which refer to which extent individuals succeeded in negotiating with other areas and elaborated joint rules for work, considering the demands brought about by the new system. This result corroborates the concept of authors that emphasize that learning the operation and new technologies is crucial to the change process (Aladwani, 2001; Bernroider \& Koch, 2001; Grant, Hall, Wailes, \& Wright, 2006).

The links between variables have disclosed very promising results for change management in public organizations. The strongest predictive power was found among the preceding variables of competences to operate the system that make up the e-process. The respondents that more frequently perceived that the adoption of the e-process brought efficiency, agility, changes to relationships and people management are those who have more intensively developed the operational competences regarding dealing with the justice system and the electronic processing of procedures. This association between change results at a macro-organizational level and competences learned at an individual level corroborates studies that have already presented this association (Combs, Liu, Hall, \& Ketchen, 2006; Raineri, 2011).

As it seems, the competences of adoption and adjustment of rules and procedures are most dependent on factors related to the context of changes, planning and readiness to carry out changes. These competences are also associated with the perception that changes have generated positive impacts on relationships and people management in the Court. The influence of planning and readiness on the changes in individuals has already been pointed out by studies by Nery and Neiva (2015) and by Neiva et al. (2012).

The competences of problems resolution and work management are associated with changes in relationships and people management and with learning support as provided by leadership. The importance of the leadership support to learning regarding the development of on the job competences has already been emphasized in previous studies (Coelho \& Borges-Andrade, 2011; Moraes, BorgesAndrade, \& Queiroga, 2011; Pantoja \& Borges-Andrade, 2004). 
The changes perceived in relationships and people management were the main predictive factor of competences learned during the introduction of the e-process in the institution. Although individuals perceived changes in relationships and people management to a lesser extent, these changes were associated with the development of on the job competences. In other words, the individuals who more intensively perceived that the work started to be performed more in groups and was managed in a different way were those who developed all kinds of competences on the job. This result reinforces the indications of authors in the field regarding the importance of people management to organizational change processes, as results are deeply interwoven (Legge, 2006; Mascarenhas, 2009; Mascarenhas \& Kirchbaum, 2008).

This study highlights the importance of studying organizational learning by focusing on the evidence of learning in practice. It represents a significant and major piece of empirical research, validating the need for links among organizational change context variables and competences learned during the change process. The study demonstrates that competencies can be used as a measure to determine levels of learning, and that any one of three broad competencies will simultaneously show equal evidence of contextual influence on learning.

Further research should determine the effect on firm performance of various competency groups at various levels of learning and in various change contexts. Following this study, future constructs should examine the differences in learning between small and large firms, especially differences in learning levels and predispositions to competency behavior of large and small firms. Future studies should also extend to other organizational change contexts with a different critical mass of competencies, and with different priorities for learning.

Finally, the instruments used in this study show validity evidence for this sample, which supports the inferences made by the study and suggests effective ways to investigate relationship between organization change, learning and work competencies. This study area presents deep theoretical speculation and little empirical support (Abbad \& Borges-Andrade, 2014). Organization change research themes in Brazil are lacking instruments with good validity and this was one of our major contribution.

In evaluating the change context, it is possible to notice the absence of change planning and preparing information among employees, which reinforces the necessity of information management for carrying out organizational changes in Brazil (Neiva \& Paz, 2012; Nery \& Neiva, 2015). Moreover the exercise of change process control through planning may not be a regular practice in this country.

During the introduction of the electronic process, the employees perceived reasonable support from colleagues and leadership. However, the results show a greater influence of peers and work sectors in learning, such that showing skills learned in the context of change are based on informal learning processes at work (Coelho \& Borges-Andrade, 2011). This group and peer influence fosters the idea that individual learning is necessary, but not a sufficient condition for organizational learning (Gould, 2000). It also supports learning as a collective process (James, 2003; Watkins \& Marsick, 1993) and that groups or teams are the main bridge through which this process is carried out.

The great contribution of the study is to establish relationships between organizational changes, learning and skills learned at work, conceiving of learning as a phenomenon at the individual level that can reverberate to other levels such as groups and organizations. So organizational changes are implemented by reverberation of this learning. The attributes of context and processes of organizational change, environmental conditions for learning occasions and perceived change results are responsible for leveraging human skills in the workplace demanded by change episodes.

These findings expand the theoretical literature on learning and organizational change with practical implications for managers and scholars. Pollack (2015) acknowledges that general management literature emphasizes an abstract understanding of knowledge management and the learning organization, while change management literature focuses more on issues associated with value, culture and social identity. The practitioners emphasized issues at the individual, project and team 
levels, the need for the effective use of targeted communication to achieve organizational change objectives, and the value of rapidly identifying key drivers in a new context.

\section{References}

Abbad, G., \& Borges-Andrade, J. E. (2014). Aprendizagem humana em organizações e trabalho. In J. C. Zanelli, J. E. Borges-Andrade, \& A. V. B. Bastos (Orgs.), Psicologia, organizações e trabalho no Brasil (2a ed., pp. 237-275). Porto Alegre: Artmed.

Abushawish, H. F., Bin Ali, A. J., \& Bin Jamil, H. (2013). Transformational leadership: winning competencies for organizations. International Journal of Business and Innovation, 1(2), 1-23. Retrieved from http://www.ijbi.info/publication/Transformational\%20Leadership\%20Winning\%20Competenci es\%20for\%20Organizations\%20Abushawish\%20et\%20al\%202013.pdf

Aladwani, A. M. (2001). Change management strategies for successful ERP implementation. Business Process Management Journal, 7(3), 266-275. Retrieved from http://citeseerx.ist.psu.edu/viewdoc/download?doi=10.1.1.87.5630\&rep=rep1\&type=pdf

Appelbaum, S., Habashy, S., Malo, J., \& Shafiq, H. (2012). Back to the future: revisiting Kotter's 1996 change model. Journal of Management Development, 31(8), 764-782. doi: $10.1108 / 02621711211253231$

Armenakis, A. A., \& Bedeian, A. G. (1999). Organizational change: a review of theory and research in the 1990s. Journal of Management, 25(3), 293-315. doi: 10.1177/014920639902500303

Ausubel, D. (2003). Aquisição e retenção de conhecimentos: uma perspectiva cognitiva. Lisboa, Portugal: Editora Plátano.

Bartunek, J. M., \& Woodman, R. W. (2015). Beyond Lewin: toward a temporal approximation of organization development and change. Annual Review Organizational Psychology and Organizational Behavior, 2, 157-182. doi: 10.1146/annurev-orgpsych-032414-111353

Battilana, J., Gilmartin, M., Sengul, M., Pache, A.-C., \& Alexander, J. A. (2010). Leadership competences for implementing planned organizational change. Leadership Quarterly, 21(3), 422438. doi: 10.1016/j.leaqua.2010.03.007

Bernroider, E., \& Koch, S. (2001). ERP selection process in midsized and large organisations. Business Process Management Journal, 7(3), 251-257. doi: 10.1108/14637150110392746

Beviláqua-Chaves, A. (2007). Estratégias de aprendizagem no trabalho em contexto de mudança organizacional (Dissertação de mestrado). Universidade de Brasília, Brasília, DF, Brasil. Retrieved from http://repositorio.unb.br/bitstream/10482/1104/1/Dissertacao_2007_AlessandraBevilaquaChave s.pdf

Brandão, H. P., Borges-Andrade, J. E., \& Guimarães, T. A. (2012). Desempenho organizacional e suas relações com competências gerenciais, suporte organizacional e treinamento. Revista de Administração da USP, 47(4), 523-539. doi: 10.5700/rausp1056

Campos, A., \& Rizzo, A. (2009, agosto 30). Entrevista com Cesar Asfor Rocha. Brasília: Correio Braziliense, p. 9. Retrieved from http://buscacb2.correioweb.com.br/correio/2009/08/30/ad103008.pdf 
Carbone, P. P., Brandão, H. P., \& Leite, J. B. D. (2005). Gestão por competências e gestão do conhecimento. Rio de Janeiro: FGV.

Cardoso, A. L. J. (2009). Percepções de gestores sobre competências gerenciais em diferentes contextos: estabilidade e mudança organizacional. Revista Brasileira de Estratégia, 2(2), 147-169. Retrieved from http://www2.pucpr.br/reol/pb/index.php/rebrae?dd99=issue\&dd0=307

Coelho, F. A., Jr., \& Borges-Andrade, J. E. (2008). Uso do conceito de aprendizagem em estudos relacionados ao trabalho e organizações. Paidéia, 18(40), 221-234. doi: 10.1590/S0103$863 \mathrm{X} 2008000200002$

Coelho, F. A., Jr., \& Borges-Andrade, J. E. (2011). Efeitos de variáveis individuais e contextuais sobre desempenho individual no trabalho. Estudos de Psicologia, 16(2), 111-120. doi: 10.1590/S1413294X2011000200001

Coetzee, R., Visagie, J., \& Ukpere, W. (2013). A proposed leadership competency model for effective organizational change intervention. Journal of Social Science, 36(3), 247-253.

Combs, J., Liu, Y., Hall, A., \& Ketchen, D. (2006). How much do high-performance work practices matter? A meta-analysis of their effects on organizational performance. Personnel Psychology, 59(3), 501-528. doi: 10.1111/j.1744-6570.2006.00045.x

Constituição da República Federativa do Brasil de 1988. (2001). [Coleção Saraiva de Legislação]. (21a ed.). São Paulo: Saraiva.

Cunningham, G. B. (2006). The relationships among commitment to change, coping with change, and turnover intentions. European Journal of Work and Organizational Psychology, 15(1), 29-45. doi: 10.1080/13594320500418766

Devos, G., Buelens, M., \& Bouckenooghe, D. (2007). The contribution of content, context, and process in understanding openness to organizational change: Two experimental simulation studies. Journal of Social Psychology, 147(6), 607-629. doi: 10.3200/SOCP.147.6.607-630

Dodgson, M. (1993). Organizational learning: a review of some literatures. Organization Studies, 14(3), 375-394. doi: 10.1177/017084069301400303

Fiol, C. M., \& Lyles, M. A. (1985). Organizational learning. Academy of Management Review, 10(4), 803-813.

Freitas, I. A., \& Brandão, H. P. (2006). Trilhas de aprendizagem como estratégia de TD\&E. In J. E. Borges-Andrade, G. Abbad, \& L. Mourão (Eds.), Treinamento, desenvolvimento e educação em organizações e trabalho: fundamentos para a gestão de pessoas (pp. 97-113). Porto Alegre, RS: Artmed.

Gould, D. (2000). Normal labour: a concept analysis. Journal of Advanced Nursing, 31(2), 418-427. doi: $10.1046 /$ j.1365-2648.2000.01281

Grant, D., Hall, R., Wailes, N., \& Wright, C. (2006). The false promise of technological determinism: the case of enterprise resource planning systems. New Technology, Work and Employment, 21(1), 2-15. doi: 10.1111/j.1468-005X.2006.00159.x

Gravenhorst, K. M. B., Werkman, R. A., \& Boonstra, J. J. (2003). The change capacity of organisations: general assessment and five configurations. Applied Psychology: An International Review, 52(1), 83-105. doi: 10.1111/1464-0597.00125

Gubbins, C., \& MacCurtain, S. (2008). Understanding the dynamics of collective learning: the role of trust and social capital. Advances in Developing Human Resources, 10(4), 578-599. doi: $10.1177 / 1523422308320372$ 
Guest, D., \& Conway, N. (2011). The impact of HR practices, HR effectiveness and a 'strong HR system' on organisational outcomes: a stakeholder perspective. The International Journal of Human Resource Management, 22(8), 1686-1702. doi: 10.1080/09585192.2011.565657

Guimarães, T. A., Odelius, C. C., Medeiros, J. J., \& Santana, J. A. V. (2011). Management innovation at the Brazilian Superior Tribunal of Justice. The American Review of Public Administration, 41(3), 297-312. doi: 10.1177/0275074010380449

Hatch, M. J., \& Ehrlich, S. B. (1993). Spontaneous humour as an indicator of paradox and ambiguity in organizations. Organization Studies, 14(4), 505-526. doi: 10.1177/017084069301400403

Huysman, M. H. (1999). Balancing biases, a critical review of the literature on organizational learning. In M. Easterby-Smith, L. Araujo, \& J. Burgoyne (Eds.), Organizational learning and the learning organization: developments in theory and practice (pp. 59-75). London: SAGE Publications Ltd. doi: 10.4135/9781446218297.n4

James, C. R. (2003). Designing learning organizations. Organizational Dynamics, 32(1), 46-61. doi: $10.1016 / \mathrm{S} 0090-2616(02) 00137-7$

Kalimo, R., Taris, T. W., \& Schaufeli, W. B. (2003). The effects of past and anticipated future downsizing on survivor well-being: an equity perspective. Journal of Occupational Health Psychology, 8(2), 91-109. doi: 10.1037/1076-8998.8.2.91

Karp, T. (2006). Transforming organisations for organic growth: the DNA of change leadership. Journal of Change Management, 6(1), 3-20. doi: 10.1080/14697010600565186

Kofman, F., \& Senge, P. M. (1993). Communities of commitment: the heart of learning organizations. Organizational Dynamics, 22(2), 5-23. doi: 10.1016/0090-2616(93)90050-B

Legge, K. (2006). Human resource management. In S. Ackroyd, R. Batt, P. Thompson, \& P. S. Tolbert (Eds.), The Oxford handbook of work and organization (pp. 220-241). New York: Oxford University Press.

Maes, G., \& Van Hootegem, G. (2011). Toward a dynamic description of the attributes of organizational change. In A. B. R. Shani, R. W. Woodman, \& W. A. Pasmore (Eds.), Research in organizational change and development (Vol. 19, pp. 191-231). Cambridge, MA: Emerald Group Publishing Limited. doi: 10.1108/S0897-3016(2011)0000019009

Mascarenhas, A. O. (2009). Gestão estratégica de pessoas: evolução, teoria e crítica. São Paulo: Cengage Learning.

Mascarenhas, A. O., \& Kirchbaum, C. (2008). Fundamentos da gestão estratégica de pessoas. In A. O. Mascarenhas (Org.), Gestão estratégica de pessoas: evolução, teoria e crítica (pp. 23-30). São Paulo: Cengage Learning.

Moraes, V. V. de, \& Borges-Andrade, J. E. (2010). Validação de escala de estratégias de aprendizagem no trabalho entre prefeitos(as) e secretários(as) municipais. Estudos de Psicologia (UFRN), 15(3), 325-334. Retrieved from http://www.scielo.br/scielo.php?script=sci_arttext\&pid=S1413294X2010000300013\&lng=en\&tlng=pt. doi: 10.1590/S1413-294X2010000300013

Moraes, V. V., Borges-Andrade, J. E., \& Queiroga, F. (2011). Construção e validação de medida para diagnóstico de competências relativas às funções de prefeito(a) e secretário(a) municipal. Revista de Administração Pública, 45(5), 1445-1461. Retrieved from http://www.scielo.br/pdf/rap/v45n5/v45n5a09.pdf. doi: 10.1590/S0034-76122011000500009

Neiva, E. R., Goulart, P. A. R., Fussi, C. C., \& Nery, V. F. (2012, setembro). Contexto e atitudes na mudança organizacional: Um estudo realizado em quatro organizações brasileiras. Anais do 
Encontro Nacional da Associação Nacional de Pós-Graduação e Pesquisa em Administração, Rio de Janeiro, RJ, Brasil, 36.

Neiva, E. R., \& Paz, M. G. T. (2012). Percepção de mudança individual e organizacional: o papel das atitudes, dos valores, do poder e da capacidade organizacional. Revista de Administração da USP, 47(1), 22-37. Retrieved from http://www.scielo.br/pdf/rausp/v47n1/v47n1a02. doi: $10.5700 /$ rausp1023

Nery, V. F., \& Neiva, E. R. (2015). Varáveis de contexto e respostas à mudança organizacional: testando o papel mediador das atitudes. Psicologia Teoria e Pesquisa, 31(2), 259-268. doi: 10.1590/010237722015021968259268

Pandey, J. P., \& Guha, S. (2014). Enhacement of competence: an effective tool for change management. International Journal of Advanced Research in Computer Science and Management Studies, 2(2), 115-120.

Pantoja, M. J., \& Borges-Andrade, J. E. (2004). Contribuições teóricas e metodológicas da abordagem multinível para o estudo da aprendizagem e sua transferência nas organizações. Revista de Administração Contemporânea, 8(4), 115-138. Retrieved from http://www.scielo.br/pdf/rac/v8n4/v8n4a07.pdf. doi: 10.1590/S1415-65552004000400007

Pollack, J. (2015). Understanding the divide between the theory and practice of organisational change. Organisational Project Management, 2(1), 35-52. doi: 10.5130/opm.v2i1.4401

Rafferty, A. E., \& Griffin, M. A. (2006). Perceptions of organizational change: a stress and coping perspective. Journal of Applied Psychology, 91(5), 1154-1162. doi: 10.1037/00219010.91.5.1154

Raineri, A. B. (2011). Change management practices: impact on perceived change results. Journal of Business Research, 64(3), 266-272. doi: 10.1016/j.jbusres.2009.11.011

Rees, C. J., \& Johari, H. (2010). Senior managers' perceptions of the HRM function during times of strategic organizational change: case study evidence from a public sector banking institution in Malaysia. Journal of Organizational Change Management, 23(5), 517-536. doi: $10.1108 / 09534811011071261$

Sadek, M., \& Cavalcanti, R. (2003). The new Brazilian public prosecution: An agent of accountability. In S. Mainwaring \& C. Welna (Eds.), Democratic accountability in Latin America (pp. 201-227). New York: Oxford University Press.

Santa, M., \& Nurcan, S. (2015). Learning organization modelling patterns. Knowledge Management Research \& Practice, 13(1), 1-20. doi:10.1057/kmrp.2014.22

Self, D., Armenakis, A., \& Schraeder, M. (2007). Organizational change content, process and context: a simultaneous analysis of employee reactions. Journal of Change Management, 7(2), 211-229. doi: 10.1080/14697010701461129

Senge, P. M. (1990). The fifth discipline: art and practice of the learning organizations. New York: Doubleday.

Watkins, K. E., \& Marsick, V. J. (1993). Sculpting the learning organization. San Francisco: JosseyBass.

Zarifian, P. (1999). Objectif compétence: pour une nouvelle logique. Paris: Editions Liaisons. 


\section{Authors' Profiles}

Elaine Rabelo Neiva

UnB, Campus Universitário Darcy Ribeiro ICC Norte, 70873-010, Brasília, DF, Brazil. E-mail address: elaine_neiva@uol.com.br

\section{Catarina Cecília Odelius}

UnB, Campus Universitário Darcy Ribeiro ICC Norte, 70873-010, Brasília, DF, Brazil. E-mail address: codelius@ gmail.com

Larissa Dutra Ramos

UnB, Campus Universitário Darcy Ribeiro ICC Norte, 70873-010, Brasília, DF, Brazil. E-mail address: larissaramos2004@hotmail.com 


\section{APPENDIX A}

\section{Scale of Context of Organizational Change}

\begin{tabular}{ccc}
\hline & \multicolumn{2}{c}{ Factor Loadings } \\
\cline { 2 - 3 } Items & Factor 1 & Factor 2 \\
\hline There was planning before the organizational change process. & 0.78 & \\
\hline This organization prepared the employees for the changes. & 0.77 \\
\hline During the change process there was training of employees. & 0.77 & \\
\hline Employees have experienced change planning. & 0.75 \\
\hline The changes have taken place in accordance with the planning. & 0.70 \\
\hline This organization prepared leaders to act in the change process. & 0.68 \\
\hline This institution provided information to employees about change & 0.67 \\
\hline implementation. & 0.65 \\
\hline Employees were prepared to act in the new scenario. & \\
\hline There was a group responsible for monitoring the change implementation. & 0.65 \\
\hline The changes involved the organization as a whole. & \\
\hline The changes were intense and deep. & 0.76 \\
\hline The changes generated risks for employees. & 0.75 \\
\hline The changes affect all employees. & 0.72 \\
\hline The changes brought danger to the welfare of employees. & 0.68 \\
\hline Changes profoundly affected the work done. & 0.65 \\
\hline
\end{tabular}




\section{APPENDIX B}

\section{Scale of Results of the Organizational Change}

\begin{tabular}{|c|c|c|}
\hline \multirow[b]{2}{*}{ Items } & \multicolumn{2}{|c|}{ Factor Loadings } \\
\hline & Factor 1 & Factor 2 \\
\hline The organization became more agile after changes. & 0.81 & \\
\hline The changes have made the organization more efficient. & 0.80 & \\
\hline $\begin{array}{l}\text { Employees perceived greater agility after electronic process } \\
\text { implementation. }\end{array}$ & 0.77 & \\
\hline The electronic process improved the control of processes. & 0.76 & \\
\hline Employees noticed more free places in the organization after changes & 0.75 & \\
\hline Employees noticed a cleaner environment after change. & 0.75 & \\
\hline The electronic process has promoted safety at work & 0.72 & \\
\hline $\begin{array}{l}\text { The electronic process implementation has brought agility to the } \\
\text { organization. }\end{array}$ & 0.68 & \\
\hline Employees are working more efficiently after the organizational change. & 0.55 & \\
\hline The electronic process implementation has improve work management. & & 0.79 \\
\hline People started to work as a team after implementing changes. & & 0.78 \\
\hline $\begin{array}{c}\text { The change process has improved the relationships between } \\
\text { organizational units. }\end{array}$ & & 0.75 \\
\hline $\begin{array}{l}\text { The electronic process has brought benefits to leader-subordinate } \\
\text { exchanges. }\end{array}$ & & 0.72 \\
\hline The change process has improved team relationships. & & 0.70 \\
\hline $\begin{array}{l}\text { The changes generated a reduction in the number of people required to } \\
\text { work. }\end{array}$ & & 0.65 \\
\hline Organizational units have begun to work together. & & 0.55 \\
\hline
\end{tabular}




\section{APPENDIX C}

\section{Scale of Support to Learning}

\begin{tabular}{|c|c|c|}
\hline \multirow[b]{2}{*}{ Items } & \multicolumn{2}{|c|}{ Factor Loadings } \\
\hline & Factor 1 & Factor 2 \\
\hline My supervisor encourages me to apply new skills and knowledge. & 0.78 & \\
\hline My supervisor appreciates my suggestions about my job. & 0.77 & \\
\hline My supervisor encourages me in taking risks in my job. & 0.76 & \\
\hline $\begin{array}{c}\text { My supervisor takes into account my ideas when they are different from } \\
\text { his. }\end{array}$ & 0.75 & \\
\hline My supervisor encourages me to face new challenges at work. & 0.65 & \\
\hline My supervisor gives me freedom as to how to develop my tasks. & 0.60 & \\
\hline $\begin{array}{l}\text { My supervisor is available to take my doubts about the use of new skills } \\
\text { and knowledge at work. }\end{array}$ & 0.57 & \\
\hline My supervisor acts in encouraging the search for new learning & 0.56 & \\
\hline $\begin{array}{l}\text { My supervisor is open to criticism when someone applies new skills and } \\
\text { knowledge in my sector. }\end{array}$ & 0.55 & \\
\hline $\begin{array}{l}\text { In my unit, there is acceptance of the risks associated with the application } \\
\text { of new skills and knowledge. }\end{array}$ & & 0.77 \\
\hline In my sector, tasks facilitate the application of new skills and knowledge. & & 0.72 \\
\hline $\begin{array}{c}\text { In my work sector, attempts to apply new skills and knowledge are } \\
\text { praised. }\end{array}$ & & 0.69 \\
\hline In my work group, people find it easy to search information about jobs. & & 0.67 \\
\hline $\begin{array}{l}\text { Accessing the information system facilitates the sharing of knowledge } \\
\text { among the people in my work group. }\end{array}$ & & 0.66 \\
\hline $\begin{array}{l}\text { In my work sector, people are encouraged to seek new information and } \\
\text { knowledge on the job. }\end{array}$ & & 0.64 \\
\hline $\begin{array}{l}\text { My group is encouraged to learn from the successful experiences of other } \\
\text { sectors and areas. }\end{array}$ & & 0.62 \\
\hline $\begin{array}{l}\text { My colleagues give me advice when I have difficulties with applying new } \\
\text { skills and knowledge. }\end{array}$ & & 0.62 \\
\hline $\begin{array}{l}\text { My colleagues encourage me to seek new skills and knowledge used on } \\
\text { job. }\end{array}$ & & 0.61 \\
\hline My colleagues encourage me to propose new ideas to perform tasks. & & 0.59 \\
\hline My colleagues feel safe when I apply new skills and knowledge at work. & & 0.55 \\
\hline
\end{tabular}




\section{APPENDIX D}

\section{Scale of Competences Learned}

\begin{tabular}{|c|c|c|c|}
\hline Items & \multicolumn{3}{|c|}{ Factor Loadings } \\
\hline During the change process I learned to... & Factor 1 & Factor 2 & Factor 3 \\
\hline Identify and access the parts and documents in the justice system. & 0.78 & & \\
\hline $\begin{array}{l}\text { Put the pieces in the electronic system by specifying the spot to } \\
\text { insert parts and numbering the pages. }\end{array}$ & 0.76 & & \\
\hline Use the text as an image and find words in it. & 0.74 & & \\
\hline Register digital petitions with digital signatures of the minister. & 0.72 & & \\
\hline Check the electronic process with the physical process. & 0.70 & & \\
\hline Separate things piece by piece to be used by ministers and analysts. & 0.69 & & \\
\hline Scan processes and parts to be used electronically. & 0.60 & & \\
\hline $\begin{array}{l}\text { Identify errors during the manipulation of the electronic process, } \\
\text { preparation of parts and analysis of parts. }\end{array}$ & 0.55 & & \\
\hline $\begin{array}{l}\text { Request permission to access the electronic process in various } \\
\text { locations including at home. }\end{array}$ & 0.55 & & \\
\hline $\begin{array}{l}\text { Establish mechanisms and rules for accessing confidential } \\
\text { proceedings. }\end{array}$ & & 0.81 & \\
\hline $\begin{array}{l}\text { Perform constant changes in the procedures for improving the } \\
\text { electronic process. }\end{array}$ & & 0.80 & \\
\hline $\begin{array}{l}\text { Be focused and attentive in all process information in order to } \\
\text { create new rules and procedures. }\end{array}$ & & 0.79 & \\
\hline $\begin{array}{c}\text { Associate the data of the justice system with the administrative } \\
\text { procedures. }\end{array}$ & & 0.77 & \\
\hline Develop agility when analyzing the electronic process. & & 0.74 & \\
\hline $\begin{array}{l}\text { Adapt the procedures of electronic process to the needs of involved } \\
\text { sectors. }\end{array}$ & & 0.70 & \\
\hline $\begin{array}{l}\text { Adapt the electronic process at the pace and conditions of other } \\
\text { court instances. }\end{array}$ & & 0.69 & \\
\hline $\begin{array}{l}\text { Adapt the procedure modifications of electronic processes created } \\
\text { by the information technology area. }\end{array}$ & & 0.67 & \\
\hline $\begin{array}{l}\text { Adapt the electronic process to the requirements and preferences of } \\
\text { the ministers. }\end{array}$ & & 0.65 & \\
\hline Create joint solutions to problems that arise. & & & 0.77 \\
\hline Make quick decisions because of electronic process demands. & & & 0.76 \\
\hline $\begin{array}{l}\text { Be available to perform various attempts to solve problems with } \\
\text { the system. }\end{array}$ & & & 0.73 \\
\hline Be willing to learn how to deal with the electronic process. & & & 0.72 \\
\hline $\begin{array}{l}\text { Establish direct and frequent connections with the computer } \\
\text { professionals. }\end{array}$ & & & 0.68 \\
\hline $\begin{array}{c}\text { Develop strategies to disseminate knowledge learned to other } \\
\text { colleagues. }\end{array}$ & & & 0.67 \\
\hline
\end{tabular}


Establish mechanisms for communication between units and co0.66 workers to solve the electronic process problems.

\begin{tabular}{cc}
\hline $\begin{array}{c}\text { Adapt unit management to the needs and demands of the electronic } \\
\text { process. }\end{array}$ & 0.65 \\
\hline Develop more efficient control mechanisms for task distribution. & 0.64 \\
\hline Develop mechanisms to monitor the tasks performed. & 0.59 \\
\hline Cooperate with co-workers. & 0.59 \\
\hline $\begin{array}{c}\text { Identify the most suitable people to cope with the electronic } \\
\text { process demands. }\end{array}$ & 0.55 \\
\hline
\end{tabular}

